\title{
The International Law of the World Ocean Protection from Oil Pollution
}

\author{
${ }^{* 1}$ Ksenia B. Valiullina, ${ }^{2}$ Adel I. Abdullin \\ ${ }^{1,2}$ Kazan Federal University, 18 Kremlyovskaya Street, Kazan, Russia, 420008 \\ E-mail: ksenia801@ list.ru, Contact. 89179329750
}

Received: 15th December 2017, Accepted: 20th December 2017, Published: 31st December 2017

\begin{abstract}
The role of the World Ocean in the global lifesupport system can't be overestimated. Covering $2 / 3$ of the surface of our planet, it is the largest supplier of Earth's oxygen and the carbon dioxide sink. It participates in climate formation, accumulating heat in summer and giving up it in winter; it ensures a continuous supply of food, consumed by the world's population. Nevertheless, over many decades, the seas and oceans are rapidly becoming contaminated from all possible sources. Practically, there are no reservoirs in the world, the water in which is suitable for drinking. They would have ceased to exist long ago without their daily replenishment with wastewater, poisoned with all sorts of substances and synthetic compounds. The sources of pollution of the marine environment are very diverse and numerous. One of the largest environmental problems of the states today is the pollution of the environment, including the marine pollution with oil and petroleum products. This occurs as due to the violation of mining and processing technology, as a result of accidents of ships, carrying oil in bulk, and in the process of their daily activities. Obviously, the importance of oil in the modern economy is very high, as its use largely determines the degree of economic development of any state. Most of it is used to produce all kinds of fuel (gasoline, diesel, ship fuel, liquefied gas, aviation fuel, heating oil). In addition, oil is used to create synthetic materials, in the production of electricity and heat. At the same time, it should be noted, that the use of oil and petroleum products, practically at all stages, from extraction to processing, involves the generation of a large amount of wastes. As a result of emissions or incineration, they release to the land, water or the atmosphere, and cause irreparable damage to the environment and human health. According to the experts, millions of tons of oil products annually enter the waters of the World Ocean. Due to this, some of the territories of seas and oceans are almost constantly covered with a dense film, oxygen-tight and destructive for living organisms and marine inhabitants. The article assesses the environmental situation in the world, with regard to the protection of the World Ocean from oil pollution. The main sources of oil and petroleum products, entering the seas and oceans were defined; and the need for the states to cooperate in ensuring the universal environmental security, through the compliance with convention provisions, was established in the article.
\end{abstract}

Keywords: World Ocean, Preservation, Oil and Petroleum Products, Oil Pollution, Cooperation, Protection and Conservation.

\section{Introduction}

"Everything in nature is linked by subtle connections. And due to this, the study of nature must be carried out holistically -in such a way as not to violate these connections; it is necessary to penetrate into the secrets of nature without destroying, but preserving and improving it. "

\section{M.V. Keldysh}

The concept of the World Ocean was developed by the Russian scientist, oceanographer, cartographer Yu.M. Shokalsky. He determines the World Ocean as a continuous water shell of the Earth, a common feature of which is the salinity of the oceans and seas, inflowing into it. For a long time, the indicated ability of the marine environment to dissolve all the entering pollutants, as well as the activity of microscopic algae in the purification of marine and oceanic waters, have contributed to the formation of an idea of the unlimited possibilities of the World Ocean for self-purification. It was assumed, that the colossal volume of the ocean, containing about 1300 million cubic $\mathrm{km}$ would manage to ensure the dilution of all the incoming harmful impurities to a safe level. Nevertheless, this assumption, unfortunately, turned out to be erroneous. Despite the existing ability of the World Ocean to selfpurification, and taking into account the presence in its environment of 45.5 billion of salts, capable of reducing the concentration of impurities, poisonous compounds enter the circulation of substances in ecosystems almost immediately after entering the water, without waiting for dilution. Considering, that there are 75,000 vessels of the merchant fleet in the World Ocean and more than 17,000 warships, the scale of pollution is enormous. Rapid pollution of the Ocean by household rubbish, plastics, sewage, oil and petroleum products, chemical and radioactive substances, and the studies of the state of marine environment indicate that the process of selfpurification of the World Ocean has slowed significantly.

\section{Methods}

The systematic structural analysis was used as a key method in the study. It helps to reveal the importance and topicality of the issue of the World Ocean 
protection from oil pollution. The combination of methods of historical and political science, and international legal analysis was used in order to ensure the correct interpretation of a number of provisions of the International Conventions, in the field of protection and preservation of the marine environment from oil and petroleum products pollution. In addition to general scientific methods, the following specific scientific methods were used to solve the issues of the research: formal-logical, comparative law, legal modeling, and logical methods, such as induction and deduction, generalization and comparison.

\section{Results and Discussions}

The whole world remembers the largest accident in the last decade on the oil platform "Deepwater Horizon" in April 2010, in the Gulf of Mexico, when more than 5 million barrels of crude oil fell into the marine environment. Hundreds of birds, fish, turtles, dolphins, whales and other marine mammals died [1]. At the same time, as a result of the activities of petroleum industry of developed countries, from 6 to 12 million tons of oil annually fall within seas and soils. This corresponds to $0.23 \%$ of the average annual oil production in the world [2]. Pollution of water bodies by petroleum products occurs as a result of accidents of tankers, carrying oil in bulk; due to the accidents on stationary drilling platforms; as a result of the deterioration of oil pipelines; in the process of tanks washing, the water in which is contaminated with oil residues. As a result of this, some areas of seas and oceans are almost constantly covered with a dense, oxygen-impermeable film [3].

Every year the world consumption of oil and petroleum products is growing catastrophically. The data of the world energy resource survey indicate that in 2017, the world oil deliveries increased by $5.8 \%$, compared to 2016 , and amounted to 47.8 million barrels per day [4]. Consequently, the need for tankers will significantly increase. At the same time, with the increase in the intensity of tanker traffic, the risk of accidental pollution of the seas and oceans, primarily with oil and petroleum products, is significantly increased. Suffice it to recall the wreck of the tanker «Torrey Canyon» in 1967 [8], off the coast of Great Britain, as a result of which 120 thousand tons of oil fell into the sea. In 1978, as a result of the crash of the supertanker "Amoco Cadiz" off the coast of France [9], 230 thousand tons of crude oil poured into the sea. Also an example of a tanker accident, which led to serious pollution of coastal waters and the Atlantic coast of Spain and France, is the accident with the Greek tanker "Prestige" in November 2002, which carried about 80,000 tons of crude oil [10].

It should be noted, that most of the oil enters the marine environment in the process of ensuring the functioning of oil tankers, for example, as a result of tank washing. According to specialists' calculations, more than $1 \%$ of oil and petroleum products from all cargo, transported by the sea, fall into the marine environment. Significant pollution with petroleum is occurred in the process of its production on oil platforms, as well as its storage and pumping through oil pipelines. According to scientists' estimates, up to $0.25 \%$ of all produced oil is lost, as a result of spills. An example is the accident on the subsea well Ixtoc-1 (Mexico), where about 5 million liters of crude oil poured out every day, due to the combustion and direct entry into the sea, for a month. [11]. If all the above are added to the unaccounted pollution from the daily incoming untreated sewage from refineries and oil depots, located in the ports and at the shores of coastal states (for example, in the United States, about half million tons of oil products fall into the sea per year), it can be imagined the whole scale of oil pollution of the World Ocean in the world, which today has global character.

At present days, the international legal protection of the World Ocean from pollution has found expression in numerous universal and regional treaties and agreements, in the field of protection and preservation of the marine environment from pollution by oil and petroleum products, due to the land activities, oil extraction and refining activities, as a result of navigation. The countries agreed on the need to cooperate on all issues, related to ensuring global environmental security, in the framework of which the protection and preservation of the marine environment is one of the key directions. In this regard, the following conventions were concluded by States, with the aim to protect the marine environment from oil pollution: International Convention for the Prevention of Pollution of the Sea by Oil, 1954; International Convention Relating to Intervention on the High Seas in Cases of Oil Pollution Casualties, 1969; International Convention for the Prevention of Pollution from Ships (MARPOL 73/78) and the International Convention on Civil Liability for Oil Pollution Damage, 1969; Convention on the Prevention of Marine Pollution by Dumping of Wastes and Other Matter, 1972. Geneva Conventions (1958) and United Nations Convention on the Law of the Sea (1982) imposed obligations on participating States to ensure the protection of the natural environment, including all its components. In particular, Part XII of the 1982 Convention is fully devoted to the protection and preservation of the marine environment. According to Article 119 of the Convention, the States are obliged to protect and preserve the marine environment. They cooperate on a worldwide or regional basis, in the process of formulation or development of international norms, standards and 
procedures for the protection and preservation of the marine environment from pollution. [12, p.261].

In these international agreements, the main attention is paid to the adoption of preventive and protective measures, in relation to a possible spill of oil and petroleum products. This means the qualitative collection and exchange of information on possible spills of oil, which can occur at any stage of the process, involving extraction, transportation and processing, and, in case of appropriate timely measures, they will not be harmful to the waters and living resources of the World Ocean. This is largely due to the fact, that major oil spills can't be eliminated completely and in the shortest possible time. Oil not only spreads over the surface of the seas, it settles to the bottom, spreads over long distances, harming not only the coastal states, but the all of mankind.

A large percentage of all pollutions of the World Ocean are not due to the accidents, but they are the results of daily operation of oil tankers, drilling rigs, petroleum refineries. Thus, the International Convention for the Prevention of Pollution of the Sea by Oil (1954) establishes a prohibition on the discharge of oil and mixtures from ships and tankers; it obliges the participating States to re-equip the ports with facilities for receiving residual oil and petroleum products from ships. The Convention on the Prevention of Marine Pollution by Dumping of Wastes and Other Matter (1972), divides all substances into three groups, among which the $1^{\text {st }}$ group includes substances, whose discharge into the marine environment is completely prohibited. Such substances include: oil and its mixtures, mercury, organochloride compounds, cadmium, chemical, biological and radioactive substances. The other two groups include substances whose discharge requires a general or special permit. A complete prohibition on the discharge of any substances, including oil, radioactive, chemical and other toxic substances, wastewater, household garbage, discharged from ships, with the exception of warships, is established by the 1973 International Convention for the Prevention of Pollution from Ships (MARPOL73/78). Coastal states are entitled to inspect ships for the legality of activities, if there is a likelihood of harm to the marine environment. In addition, the most vulnerable areas have been identified, where the discharge of any poisonous substances is strictly prohibited, such as: the Mediterranean Sea, the Black Sea, the Red Sea, the Persian and Oman Gulfs. With regard to the high seas, the right of States to take decisive measures to prevent, reduce or eliminate the threat of pollution of the marine environment of their coast is included, which means both the enforcement of coercive measures to eliminate accidents and the possibility of sinking the vessel, in case of real threat of large-scale coastal pollution. Such issues are regulated by the International Convention Relating to Intervention on the High Seas in Cases of Oil Pollution Casualties (1969). It introduces significant restrictions on the principle of the exclusive jurisdiction of flag States over their vessels, which was proclaimed by the Geneva Convention on the High Seas [13]. These measures should be definitely commensurate with the possible damage, since as a result of exceeding their authority and causing damage to the other party, compensation must be paid in the amount of damage to the flag State. As for the compensation for damage to the coastal state, such issues are regulated by the 1969 International Convention on Civil Liability for Oil Pollution Damage. The provisions of the Convention indicate the existence of a fund for damages, since the consequences can be so great, that it is impossible to pay for damage by one or more persons or organization.

The United Nations Convention on the Law of the Sea (1982) includes a number of provisions, regulating the protection of the marine environment from oil pollution. First of all, it should be noted the norm, according to which, the States independently or with the support of international organizations provide assistance to developing countries, on the issues of pollution of the marine environment, including the training of relevant personnel, provision of the necessary equipment, and technical assistance for the creation of such equipment, the assistance in their participation in international programs, the advising on research, monitoring and other programs (Art. 202). The consolidation of these provisions exists due to the lack of environmental programs in developing countries, the inability to join a number of international conventions, or the implementation of convention norms. It affects primarily neighboring developed countries, whose environmental activities are practically ineffective in such conditions. The Convention also establishes the duty of States, acting jointly and with the support of international organizations, to carry out an analysis of the risks and consequences of pollution of the marine environment, as a result of activities, which they commit or permit (Art. 204).

\footnotetext{
Summary

Despite the existence of a quite large number of international legal instruments, the continuing process of pollution of the World Ocean, allows to conclude, that not all states participate equally in their implementation, in the protection of the World Ocean from oil pollution. Not all countries are the parties to a number of international conventions in this area, and the participant-states to international treaties often do not take active steps towards the
} 
introduction of provisions, and the implementation of convention norms in domestic legislation.

The continuing process of pollution of the World Ocean is explained by a number of reasons:

- The ecological consciousness is insufficiently developed, based on the understanding of the importance of ensuring protection and preservation of the marine environment from pollution for all mankind;

- Developing states, sometimes, do not have the necessary resources and scientific personnel to ensure the provisions of a number of Conventions;

- The cost of environmentally friendly equipment is so high, that it is easier to pay fines for "nonenvironmental activities";

- the institution of responsibility in the international law is very poorly developed, therefore, the regulation of the issue of responsibility for environmental violations is most often carried out at the level of national legislation, which establishes fines for causing environmental damage, easily covered by enterprises;

- The process of information exchange on oil spills is poorly developed;

- Not all the states monitor the condition of ships and oil pipelines, while many of them have fallen into disrepair long ago. Everywhere there is a process of concealing information on oil spills, that is easily ensured in the absence of the state's ability to monitor objects from the air. As a result, when the violation is discovered, the question of finding the guilty becomes extremely difficult. The process of eliminating the consequences of discharge the oil and petroleum products, which in a few days are able as to sink to the seabed, as to spread over long distances, becomes significantly complicated.

\section{Conclusion}

Obviously, to ensure the strict compliance with all the provisions of the United Nations Convention on the Law of the Sea of 1982, and other international treaties and agreements in the field of protection the oceans from oil pollution, is for many reasons a long and labor-intensive process, which can be realized only with the support of international organizations, on the basis of international law and in the process of close cooperation of states, on the worldwide and regional basis. Currently, it is possible to fight with the unwillingness of large companies to carry out environmentally sound activities, as through the system of financial penalties, with compulsory accounting of received multi-billion profit, as well as through benefits for "clean" activity, from the ecological point of view, when the priority of environmental safety will be assessed neither as punishment, but as the emergence of additional economic opportunities. Nevertheless, to date, the main contribution to protection and preservation the marine environment from oil pollution is provided, above all, by scientists, who develop new methods of oil collection after the spills.

Summing up the research, we would like to quote the words of the great researcher of the World Ocean and the sea depths Zh.I. Kusto: "We should not allow to poison the World Ocean forever, at the very time, when we only begun to understand, what it can give to science, began to learn how to live in its bosom".

\section{Acknowledgements}

The work is performed according to the Russian Government Program of Competitive Growth of Kazan Federal University.

\section{References}

[1] Jason Schwartz. Making 4 years since the BP Deepwater Horizon blowout. Greenpeace Organization. Available at: http://www.greenpeace.org/usa/marking-4-yearssince-bp-deepwater-horizon-blowout/.

[2] Duryagina E.G. Petroleum products in the marine environment. Proceedings of the Russian State Hydrometeorological University. St. Petersburg. №17. 2011. P.122.

[3] Kolodkin A.L., Gutsulyak V.N., BobrovaYu.V. The World Ocean: the international legal regime: the main problems. Moscow: Statut 2007. P. 315.

[4] Oil market report. International Energy Agency. Secure Sustainable Together. Available at: Oil market report. International Energy Agency. Secure Sustainable Together.

[7] Albert E. Utton. Protective measures and the "Torrey Canyon". Boston college law review.Article4. 1968. vol.9. №4.

[8] Ecological study of the Amoco Cadiz oil spill: Report of the NOAA-CNEXO Joint scientific Commission. October, 1982.

[9] Prestige oil tanker disaster crew acquitted in Spain. BBC News. Europe. November. 2013. Available at: http://www.bbc.com/news/worldeurope-24930976.

[10] IXTOC I Oil Spill Gulf of Mexico1979. Available at: https://wn.com/ixtoc_i_oil_spill.

[11] United Nations Convention on the Law of the Sea $1982 . \quad$ [web-site] http://www.un.org/depts/los/convention_agreement s/texts/unclos/unclos_e.

[12] Geneva Convention on the High Seas, 1958 (Ratified by Nepal on $28^{\text {th }}$ December, 1962). Availableat:

http://www.lawcommission.gov.np/en/documents/2 $\underline{015 / 08 / \text { geneva-convention. }}$ 